\title{
Strategies for Detection of Sexually Transmitted Infection Among Family Planning Clients in Jamaica
}

\author{
By Elizabeth Ward, Alan Spruyt, Laurie Fox, Laura Johnson, Emelita Wong, Frieda Behets, J. Peter Figueroa and Jo M orris
}

\begin{abstract}
Context: Family planning clinics that plan to add sexually transmitted infection (STI) services should consider alternatives to modified World Health Organization (WHO) risk-inclusive algorithms for identifying infected women.
\end{abstract}

Methods: A sample of 767 family planning clients from Kingston, Jamaica, were interviewed and examined, and specimens were obtained to detect the agents that cause gonorrhea, chlamydia and trichomoniasis. Serum was tested to detect the bacteria that cause syphilis. Decision models for classifying women with STI were compared using clinical and statistical criteria. Models included STI classifications based on the weighted sum of STI risk factors, on the presence of two or more factors identified via an interview or on an interview augmented with a urine dipstick test (i.e., rapid risk assessment). These models were compared with a modified WHO algorithm originally intended for STI clients in Jamaica.

Results: Individual factors associated with gonorrhea, chlamydia and trichomoniasis were urine leukocyte esterase dipstick test outcomes greater than 1+ (indicating the likelihood of infection based on the concentration of white blood cell enzymes, on a scale of negative, trace, $1+, 2+$ and 3+), multiple partners in the past year, friable cervix and age less than 25 years. An additional risk factor for cervical infection alone (gonorrhea or chlamydia) was spotting after sex. Reported vaginal discharge was not significantly associated with infection. For cervical infection, the WHO risk-inclusive algorithm was least accurate (a positive predictive value of $14 \%$ ), the weighted-risk algorithms were best (a positive predictive value of $23 \%$ ), while the interview-alone and the rapid risk assessment were slightly less accurate (positive predictive values of 20\%).

Conclusions: The modified WHO risk-inclusive algorithm appeared inappropriate for asymptomatic women. The rapid risk assessment was easier to perform and more predictive. Urine leukocyte esterase dipstick tests may be useful when pelvic examinations are not feasible. The STI assessment models, other than the WHO algorithm, should be evaluated in other settings where STI prevalence is high, or where patients are unlikely to seek further evaluation, to better identify women in need of counseling, further evaluation or treatment.

International Family Planning Perspectives, 2001, 27(3):201-207

$\mathrm{T}$ The World Health Organization (WHO) estimated that globally there were 333 million cases of sexually transmitted infections (STIs) in $1995 .{ }^{1}$ Most of these infections occurred among women of reproductive age. ${ }^{2}$ Untreated chlamydial and gonococcal infections are associated with pelvic inflammatory disease, ectopic pregnancy, infertility and neonatal infection. Evidence from a randomized, controlled trial in Tanzania suggests that treatment of STIs can decrease the incidence of HIV infection. ${ }^{3}$ In response to the HIV epidemic, calls were made at the 1994 International Conference on Population and Development in Cairo and at the Fourth World Conference on Women in Beijing in 1995 for the integration of STI prevention and treatment services into existing family planning and maternal and child health programs.

Just as all family planning service delivery points do not offer all contraceptive services, they may not be able to offer the entire range of STI services, from prevention counseling and promotion of simultaneous barrier and nonbarrier method use for dual protection to STI management and partner notification. Policymakers and family planning program managers are responsible for making decisions about program expansion according to the STI prevalence among their family planning clients and the availability of resources for prevention, diagnosis and treatment. Mechanisms that identify clients at greatest risk of having an STI would help programs optimize the use of their STI prevention and care resources. ${ }^{5}$

There is a considerable body of research on STI risk factors. Studies suggest that the usefulness of these risk factors for the purposes of STI screening varies and is strongly dependent on the prevalence of infection and on other characteristics of a given population. ${ }^{6}$ Most studies among family planning clients suggest that risk factors are not sufficiently predictive to be useful as STI screening tools. ${ }^{7}$ This may be due in part to a relatively low prevalence of infection, as well as a woman's risk of infection being less dependent on her behavior than on that of her partner, which is difficult to evaluate. ${ }^{8}$ In settings with higher STI prevalence, overtreatment resulting from the use of risk factors or other nonspecific presumptive treatment tools might be considered an acceptable sacrifice for the sake of reducing STI transmission. ${ }^{9}$

Syndromic management of STIs uses algorithms based on common signs and symptoms to guide presumptive treatment. Use of a vaginal discharge algorithm for women is limited by its dependence on symptoms. Many women infected with STIs are asymptomatic, and among symptomatic women, signs and symptoms are often nonspecific and may not be related to sexual behavior. ${ }^{10} \mathrm{Re}$ searchers have tried to improve the performance of vaginal discharge algorithms among women by adding social and demographic risk characteristics to create algorithms with higher sensitivity and specificity. ${ }^{11}$

The analysis described in this article was undertaken to identify risk factors for common STIs and to investigate the accuracy of STI algorithms among a sample of fam-

Elizabeth Ward is epidemiologist with the Epidemiology Unit of the Ministry of Health, Kingston, Jamaica. Alan Spruyt is research associate with Health Services Research (HSR), Family Health International (FHI), Research Triangle Park, NC, USA. Laurie Fox was a research associate with FHI at the time of the study, and currently is a practicing clinician in Carrboro, NC, USA. Laura Johnson is senior research analyst and Emelita Wong is associate director with Biostatistics, HSR/FHI, Research Triangle Park, NC, USA. Frieda Behets is research assistant professor, Department of Medicine and Departmen of Epidemiology, School of Public Health, University of North Carolina, Chapel Hill, NC, USA. J. Peter Figueroa is chief medical officer with the Epidemiology Unit of the Ministry of Health, Kingston, Jamaica. Jo Morris is Research Statistician in the Centre for Cancer and Palliative Care Studies, Institute of Cancer Research, Surrey, UK. The work on which this article is based was funded by the U.S. Agency for International Development (USAID), contract AID/DPE-3041-A-00-0043-00. The views expressed in this document, however, do not necessarily reflect those of the funding agency or FHI. The authors would like to thank the staff of Glen Vincent Health Centre, Lenworth Jacobs Clinic and Comprehensive Laboratory for their invaluable contributions necessary for carrying out this study. 
Figure 1. WHO algorithm modified for use in Jamaican STI clinics

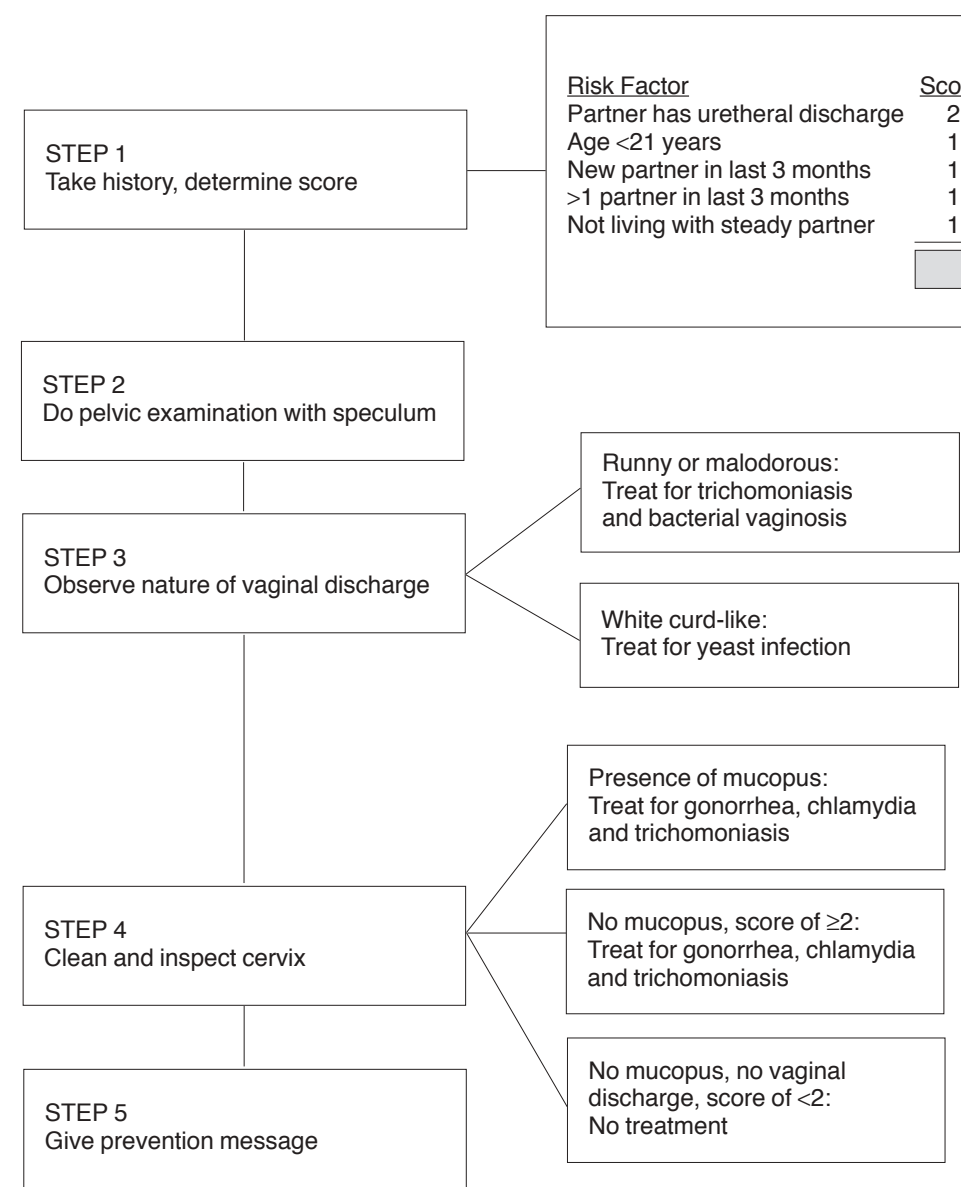

ily planning clients in Jamaica. A previously published analysis indicated that $27 \%$ of these women had an STI. ${ }^{12}$ Building on this previous research, we used multivariable statistical analyses to reevaluate STI risk factors and to create and assess modified decision models. The goal is to develop practical, efficient and effective strategies to identify women with STIs during routine family planning visits, in order to offer prevention information, additional STI education, condoms and some form of STI management or referral services, thereby optimizing each clinic contact.

\section{Methodology \\ Data Collection}

A cross-sectional survey was used to collect information on STI prevalence and risk factors from clients of one public and one private nonprofit family planning

\footnotetext{
*No one younger than 18 was allowed to participate in this study, to comply with Family Health International's Protection of Human Subjects Committee.

tA more detailed description of the data collection and laboratory methods is presented in reference 12 .
}

clinic in Kingston, Jamaica. Women between 18 and 49 years of age* who were not pregnant and who had been using a family planning method during the six months prior to the study were eligible to participate in the survey. Informed consent was required for enrollment.

The women were interviewed about their social and demographic characteristics, STI history, sexual behaviors and contraceptive use. Nurse clinicians were trained to perform pelvic examinations and collect specimens to assess the acidity $(\mathrm{pH})$ of vaginal fluids and confirm the presence of Neisseria gonorrhoeae (using a modified Thayer-Martin culture [BBL; Becton-Dickinson, Cockeysville, MD, USA]), Chlamydia trachomatis (using an enzyme-linked immunoassay [Baxter Bartels, Dundee, Scotland]) and Trichomonas vaginalis (using an InPouch culture [Biomed Diagnostics, San Jose, CA, USA]). A laboratory assistant tested urine samples using a leukocyte esterase dipstick (Ames, Chicago, IL, USA). ${ }^{\dagger}$ The dipstick changes color, depending on the concentration of white blood cell enzymes in the urine (on a scale of negative, trace, $1+, 2+, 3+)$, thus indicating the likelihood of an infection. Women identified as infected by means of a vaginal discharge algorithm (a diagnostic and treatment algorithm based on sexual history, symptoms and clinical signs, as outlined in Figure 1) were given free treatment for gonorrhea, chlamydia or trichomoniasis at the initial visit. All women were asked to return in seven days for the results of laboratory testing. Those with positive laboratory results but who had not received medication were treated at the follow-up visit. Women who received treatment were also given free medication for their partners.

\section{Statistical Methods}

Questionnaire data were double-entered and verified using Epi Info 6.0 (Centers for Disease Control and Prevention, Atlanta, GA, USA), and analyzed using SPSS 6.1 for Windows (SPSS Inc., Chicago, IL, USA) and SAS 6.11 for Windows (SAS institute, Cary, NC, USA). To determine individual factors related to infection, we calculated odds ratios and $95 \%$ confidence intervals for each potential risk factor. Using multiple logistic regression, we analyzed all factors found to be significant through bivariate analysis ( $\mathrm{p} \leq .05)$. In addition, we included other commonly recognized risk factors, such as having a partner with other partners or a partner with urethral discharge, which were not statistically significant in bivariate analysis. We excluded variables that were significant in bivariate analysis from the multiple logistic regression if they were highly correlated with other independent variables that were more inclusive (those with Spearman correlation coefficients of 0.3 or more).

When gonorrheal, chlamydial or trichomonal infections are symptomatic, they are often characterized by an abnormal vaginal discharge. In this analysis, we therefore grouped the three infections as one outcome variable. In a separate analysis, cervical infection caused by $N$. gonorrhoeae or C. trachomatis was considered a dependent variable because of the serious sequelae associated with untreated cervical infection.

We evaluated our decision models for their ability to correctly identify women with gonorrhea, chlamydia or trichomoniasis, based on measures of sensitivity, specificity and positive predictive value. (Positive predictive value is defined as the proportion of women with infections confirmed by laboratory analysis out of the women identified or selected by the decision model.) Models were compared with 
a WHO-based algorithm, modified for use in Jamaican STI clinics (Figure 1). ${ }^{13}$ We did not separately analyze algorithms among the subset of women who reported a discharge, since vaginal discharge was not significantly associated with cervical infection or trichomoniasis. All women, regardless of symptoms, are included in the analyses. Decision models for syphilis were not evaluated, since simple laboratory screening for syphilis among low-risk women has been shown to be cost-effective. ${ }^{14}$

The two weighted scoring models are based on risk scores assigned to each significant risk predictor. Similar to methods used by Vuylsteke ${ }^{15}$ we multiplied the coefficients of significant covariates (identified through logistic regression) by 10 . A woman's risk score is the sum of the products derived from each covariate. Women are categorized as infected with an STI if their total score is greater than or equal to a given cut-off score (nine or more in Model 1, and eight or more in Model 2). Reported spotting or bleeding after sex may be clinically related to a friable cervix (one that easily bleeds upon contact, e.g. with a cotton swab); thus, to simplify the model, we removed cervical friability from the second model and substituted postcoital spotting, thereby eliminating the need for a pelvic examination.

The rapid risk-assessment model is based on six risk factors that were either confirmed through multiple logistic regression analysis (positive urine dipstick result, more than one partner in the past year, younger than 25 and spotting or bleeding after sex) or other commonly recognized factors (partner who has other partners and partner who has urethral discharge). ${ }^{16}$ Again, we replaced cervical friability with postcoital spotting. A woman with two or more risk characteristics was classified as infected. For comparison, we also present a model including interview information alone (designated as "risk questions"); this decision model is identical to the rapid risk assessment without the urine test.

\section{Results}

A total of 782 female family planning clients were recruited from June to November 1995. Fifteen women who completed the risk-factor questionnaire were excluded for failure to complete the medical examination, leaving 767 (98\%) who were included in the analysis.

Multiple logistic regression ( $\mathrm{p} \leq .05$ ) identified four significant risk factors for gonococcal, chlamydial or trichomonal infection: having a urine dipstick result greater than
1+, having had more than one partner in the past year, having a friable cervix on examination or being younger than 25 (Table 1). Factors found to be significant only through bivariate analysis included spotting after sex, vaginal odor, more than one partner in the past three months and a casual partner or a partner who has other partners.

Multivariable analysis identified urine dipstick results greater than $1+$, more than one partner in the past year, a friable cervix on examination, being younger than 25 years and spotting after sex as risk factors for cervical infection alone (gonococcal or chlamydial). Bivariate analysis suggests that having had more than one partner in the past three months was also related to cervical infection (Table 2, page 204).

In identifying gonorrhea, chlamydia or trichomoniasis in this sample of family planning clients, the WHO-based risk-inclusive algorithm modified for Jamaican STI clients (Figure 1) was $58 \%$ sensitive, was $46 \%$ specific and had a positive predictive value of $25 \%$ (Table 3, page 205). ${ }^{17}$ In comparison, the two weightedrisk algorithms (Models 1 and 2) and the rapid assessment model were more accurate, with positive predictive values of $39 \%, 38 \%$ and $35 \%$, respectively. The risk questions alone outperformed the $\mathrm{WHO}-$ based algorithm in terms of positive predictive value $(34 \%)$, although this approach was slightly less sensitive (54\%) than the others (58-71\%).

The relative accuracy of these approaches for identifying cervical infection but not trichomoniasis was similar to that found for all STIs. The modified WHO risk-inclusive algorithm was least effective in assessing the likelihood of current gonococcal or chlamydial infections based on the positive predictive value (14\%). The weighted-risk algorithms had the highest positive predictive values $(23 \%)$, while the rapid risk assessment and the risk questions were slightly less predictive than the weighted models (20\% each) but more so than the WHO algorithm.

\section{Discussion}

Health policymakers are faced with the growing STI problem among populations traditionally considered at lower risk. Almost all of the participants in this study were family planning clients who presented for routine contraceptive management; however, more than one-quarter were diagnosed with at least one of four STIs. Most women were asymptomatic or did not recognize their symptoms 
Table 2. Percentage of family planning clients with (gonorrheal or chlamydial) cervical infection, and bivariate and multivariate odds ratios (with $95 \%$ confidence intervals), all by selected characteristics

\begin{tabular}{|c|c|c|c|c|}
\hline \multirow[t]{2}{*}{ Characteristic } & \multicolumn{2}{|c|}{ Prevalence } & \multirow{2}{*}{$\begin{array}{l}\text { Bivariate } \\
\text { odds ratio }\end{array}$} & \multirow{2}{*}{$\begin{array}{l}\text { Multivariate } \\
\text { odds ratio }\end{array}$} \\
\hline & $\mathrm{N}$ & $\%$ & & \\
\hline Total & 108 & 14.1 & na & na \\
\hline \multicolumn{5}{|l|}{ Age } \\
\hline$\geq 25$ & 63 & 11.8 & 1.0 & 1.0 \\
\hline$<25$ & 45 & 19.4 & $1.8(1.2-2.7)$ & $1.8(1.2-2.8)$ \\
\hline \multicolumn{5}{|c|}{ Reported unpleasant vaginal odor } \\
\hline No & 90 & 13.3 & 1.0 & 1.0 \\
\hline Yes & 18 & 19.6 & $1.6(0.9-2.8)$ & $1.0(0.6-1.9)$ \\
\hline \multicolumn{5}{|c|}{ Reported bleeding/spotting after sex } \\
\hline No & 93 & 13.0 & 1.0 & 1.0 \\
\hline Yes & 15 & 27.8 & $2.6(1.4-4.8)$ & $2.1(1.1-4.1)$ \\
\hline \multicolumn{5}{|l|}{ Cervical friability } \\
\hline No & 80 & 12.1 & 1.0 & 1.0 \\
\hline Yes & 28 & 26.2 & $2.6(1.6-4.2)$ & $2.2(1.3-3.7)$ \\
\hline \multicolumn{5}{|l|}{ Urine LED } \\
\hline Neg/trace/+ & 68 & 11.4 & 1.0 & 1.0 \\
\hline$++/+++$ & 39 & 23.2 & $2.3(1.5-3.6)$ & $2.1(1.3-3.4)$ \\
\hline \multicolumn{5}{|c|}{ New partner in last 3 months* } \\
\hline No & 97 & 13.9 & 1.0 & ne \\
\hline Yes & 11 & 15.5 & $1.1(0.6-2.2)$ & ne \\
\hline \multicolumn{5}{|c|}{ No. of partners in last 3 months* } \\
\hline 1 & 92 & 13.1 & 1.0 & ne \\
\hline$\geq 2$ & 16 & 25.0 & $2.2(1.2-4.1)$ & ne \\
\hline \multicolumn{5}{|c|}{ No. of partners in last year ${ }^{\star}$} \\
\hline 1 & 79 & 12.6 & 1.0 & 1.0 \\
\hline$\geq 2$ & 28 & 20.9 & $1.8(1.1-3.0)$ & $1.7(1.0-2.9)$ \\
\hline \multicolumn{5}{|c|}{ Has a casual partner* } \\
\hline No & 102 & 13.7 & 1.0 & ne \\
\hline Yes & 6 & 24.0 & $2.0(0.8-5.1)$ & ne \\
\hline \multicolumn{5}{|c|}{ Partner may have other partners } \\
\hline No & 21 & 10.4 & 1.0 & 1.0 \\
\hline Yes/d00o not know & 86 & 15.2 & $1.5(0.9-2.6)$ & $1.2(0.7-2.0)$ \\
\hline \multicolumn{5}{|c|}{ Partner has urethral discharge } \\
\hline No & 105 & 13.8 & 1.0 & 1.0 \\
\hline Yes & 3 & 37.5 & $3.7(0.9-15.9)$ & $3.0(0.6-14.3)$ \\
\hline
\end{tabular}

*Spearman correlation coefficients $\geq 0.3$ for having a new partner in the last 3 months, number of partners in last 3 months and number of partners in last year, and for number of partners in last 3 months, number of partners in last year and having a casual partner. Notes: na=not applicable; ne=not entered in model. and symptomatic family planning clients, we attempted to develop acceptable alternative decision models to identify women at highest risk of current infection during routine family planning visits. Ideally, decision models could be used to focus STI prevention activities, to select or defer IUD candidates, to offer presumptive treatment for the patient and the patient's partner, or to refer them for further evaluation and treatment.

Multivariable analysis identified several individual predictors of infection that have been significant in other research. A urine dipstick reading greater than $1+$ was significantly associated with cervical infections or trichomoniasis, and was the strongest predictor in the cervicitis and vaginitis model. Other research suggests varying degrees of association between a positive urine dipstick result and infection among women. For detection of gonorrhea, one study among female STI clients found the urine dipstick to be as accurate as Gram stains. ${ }^{19}$ For detection of gonorrhea or chlamydia, the same study found the urine as abnormal and potentially treatable until questioned. Even among women who reported vaginal discharge, this symptom was not a significant predictor of cervical infections or trichomoniasis. These findings and others suggest that it is often difficult to correctly identify women with STIs based on symptoms. ${ }^{18}$

Our original goal was to assess STI prevalence and to identify risk factors among family planning populations in Jamaica. These individual factors are the basis for decision models designed to identify infected women. We tested the Jamaica STI clinic algorithm (i.e., the modified WHO algorithm) for its usefulness among this lower-risk group. Finding it an ineffective STI management tool among asymptomatic clients worldwide, age is the best predictor of chlamydial infection, with younger age-groups being at higher risk of infection. ${ }^{23}$ Although less commonly evaluated, cervical friability was identified as a predictor of cervical infection or trichomoniasis in this and other developing countries..$^{24}$ Several other STI risk factors identified in other research were not found to be significant here: being unmarried or single, ${ }^{25}$ currently using injectable hormones, oral contraceptives or IUDs; ${ }^{26}$ having a vaginal discharge, ${ }^{27}$ experiencing vaginal itching, ${ }^{28}$ experiencing cervical motion tenderness; ${ }^{29}$ or having a partner with urethral discharge. ${ }^{30}$

In the analysis of the data collected in Jamaican family planning clinics, we evaluated algorithms that included demographic and behavioral risk factors for their ability to identify women with gonorrhea, chlamydia or trichomoniasis. Decision models for the management of any one of the three infections (rather than cervical infection alone) might be used for counseling and referral, but not for presumptive treatment. Consistent with findings of other research, ${ }^{31}$ the WHO modified risk-inclusive algorithm was the least predictive. The proportion of infected women among those selected by the algorithm was comparable to the prevalence of infection in the entire study population; thus, it performed no better than chance. Moreover, this approach is the most complicated to use. Results here suggest that it is an inappropriate screening tool for women who are not already seeking STI services.

It should be emphasized that the WHO STI algorithm was not developed for use with asymptomatic clients (men or women). The WHO recognizes that the algorithms are not necessarily applicable across regions and recommends that syndromic approaches be tested and modified among local populations before being implemented. Among symptomatic clients seeking care, decision models that rely on a physical examination have been shown to be useful to identify pelvic inflammatory disease, epididymitis, genital ulcer syndrome and bacterial vaginosis. ${ }^{32}$

In this article, the weighted-risk models were more predictive than the modified WHO algorithm; however, Model 1 requires a physical examination, and both weighted models rely on calculation of a risk score. Experience has shown that providers do not always accept the use of risk scores, and that calculation may sometimes be viewed as complicated and bothersome. The accuracy of the rapid risk as- 
sessment was similar to the weighted-risk algorithms, with several advantages. This simple tool requires minimal training and inexpensive supplies. No clinical examination is required, and staff need not calculate risk scores. Training, facilities, equipment and supplies required for pelvic examinations (electricity, sterilizer, examining tables, lamps, specula and drapes) are unnecessary. Even without access to urine dipsticks, providers may find the risk questions alone preferable to the WHO algorithm for identifying family planning clients in need of STI counseling, referral or presumptive treatment.

Few family planning programs in developing countries have the human resources or capital to enable staff to perform hygienic and effective pelvic examinations in settings other than scarce private or hospital-based clinics. The high level of asymptomatic infection remains an STI management dilemma for clinicians faced with limited access to diagnostic laboratory tests. A recent review of non-laboratory-based decision models suggests that they are generally not sensitive or specific enough to be used for identification of infection among antenatal and family planning populations. ${ }^{33}$ The results of our analysis support these assertions.

Among the decision models evaluated for detection of cervical infection, the highest positive predictive value was only $23 \%$ (weighted scoring). Other studies suggest that among populations with a lower prevalence of infection, decision models for screening or management of cervical infection may result in positive predictive values even lower than those here. ${ }^{34}$ This should serve to remind program managers of the importance of considering the prevalence of a particular infection in a given population before they implement decision models. Nevertheless, as mentioned above, in order to curb STI transmission among family planning populations with high STI prevalence, overtreatment resulting from use of risk factors or other nonspecific presumptive treatment tools might be justified, ${ }^{35}$ particularly given that there are single-dose treatments that are relatively inexpensive, safe and easy to administer.

For effective control, the prevention and management of STIs must become a higher priority for health care providers serving sexually active populations who were previously assumed to be at lower STI risk. ${ }^{36}$ To optimize each contact, providers should offer women prevention information and condoms. Risk evaluation, presumptive treatment, etiologic diagnosis and

Table 3. Risk factors and scores, sensitivity, specificity, positive predictive value and decision criteria for selected decision models for identification of STIs among Jamaican family planning clients, according to type of STIs

\begin{tabular}{|c|c|c|c|c|}
\hline $\begin{array}{l}\text { Decision model and } \\
\text { risk factors }\end{array}$ & Sensitivity & Specificity & $\begin{array}{l}\text { Positive predic- } \\
\text { tive value }\end{array}$ & $\begin{array}{l}\text { Decision } \\
\text { criteria }\end{array}$ \\
\hline GONORRHEA/CHLAMYDIA & NIASIS & & & \\
\hline $\begin{array}{l}\text { WHO algorithm } \\
\text { Age }<21(1) \\
\text { New partner in } 3 \text { months (1) }\end{array}$ & 57.7 & 46.2 & 25.0 & $\begin{array}{l}\text { Score } \geq 2 \text { or } \\
\text { clinical signs } \\
\text { (see Figure 1) }\end{array}$ \\
\hline
\end{tabular}

New partner in 3 months $(1)$

$>1$ partner in last 3 months (1)

Not living with steady partner (1)

Partner has urethral discharge (2)

\section{Weighted scoring model 1}

Age $<25(5)$

$>1$ partner in last year $(9)$

Cervical friability (6)

Urine leukocyte esterase ( $\geq++)$ (11)

Weighted scoring model 2

Age $<25$ (5)

Score $\geq 9$

$>1$ partner in last year $(9)$

Spotting/bleeding after sex (6)

urine leukocyte esterase $(\geq++)(12)$

Rapid risk assessment

Age $<25$

$>1$ partner in last year

Partner has other partners

Partner has urethral discharge

Spotting/bleeding after sex

Urine leukocyte esterase $(\geq++)$

Risk questions

Age $<25$

$>1$ partner in last year

Partner has other partners

Partner has urethral discharge

Spotting/bleeding after sex

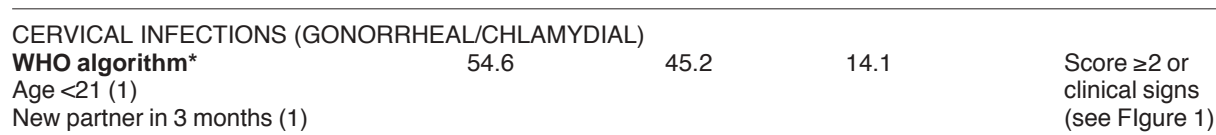

$>1$ partner in last 3 months $(1)$

(see Flgure 1)

Not living with steady partner (1)

Partner has urethral discharge (2)

Weighted scoring model 1

Age <25 (6)

56.1

69.4

37.5

Score $\geq 9$

$>1$ partner in last year (6)

Cervical friability (8)

Urine leukocyte esterase ( $\geq++)$ (8)

Weighted scoring model 2

Age $<25$ (6)

$>1$ partner in last year (5)

Spotting/bleeding after sex (8)

urine leukocyte esterase $(\geq++)(9)$

\section{Rapid risk assessment}

Age $<25$

$>1$ partner in last year

Partner has other partners

Partner has urethral discharge

Spotting/bleeding after sex

Urine leukocyte esterase $(\geq++)$

Risk questions

Any 2

\section{Age $<25$}

$>1$ partner in last year

Partner has other partners

Partner has urethral discharge

Spotting/bleeding after sex

*Modified for Jamaican STD clients. Note: Numbers in parenthesis are scores assigned to risk factors.

treatment, or referral services should be provided to the extent that resources allow in areas where STI prevalence may be high.

Reliable and economical STI classifica- tion techniques that do not require physical examinations are urgently needed. Non-laboratory-based decision models can be used to select or refer women for 
further evaluation and treatment, or to offer presumptive treatment where resources allow, where prevalence suggests or when the patient is unlikely to seek further evaluation.

Until methods such as DNA amplification techniques are globally available, the rapid risk assessment and other STI decision models should be evaluated in semiurban and rural sites in Jamaica or other settings with similar populations. Economic analysis of different management strategies will also enable health policy officials to make more informed choices among alternative approaches.

\section{References}

1. Division of AIDS and STD, World Health Organization (WHO), WHO Fact Sheet, Geneva: WHO, April 1996.

2. Holmes KK et al., eds., Sexually Transmitted Diseases, New York: McGraw-Hill, 1990

3. United Nations (UN), Programme of Action of the United Nations International Conference on Population and Development, New York: UN, 1994.

4. UN, 1995 Fourth World Conference on Women, Plan of Action, Beijing, Sept. 4-15, 1995; and Grosskurth H et al., Impact of improved treatment of sexually transmitted diseases on HIV infection in rural Tanzania: randomised controled trial, Lancet, 1995, 346(8974):530-536.

5. Fox LJ et al., Improving reproductive health: integrating STD and contraceptive services, Journal of the American Medical Women's Association, 1995, 50(3-4): 129-136; and Miller WC, Screening for chlamydia infection: a model program based on prevalence, Sexually Transmitted Diseases, 1998, 25(4):201-210.

6. Miller WC, 1998, op. cit. (see reference 5); Vuylsteke B et al., Clinical algorithms for the screening of women for gonococcal and chlamydial infection: evaluation of pregnant women and prostitutes in Zaire, Clinical Infectious Diseases, 1993, 17(1):82-88; and Dallabetta GA, Gerbase $\mathrm{AC}$ and Holmes KK, Problems, solutions, and challenges in syndromic management of sexually transmitted diseases, Sexually Transmitted Infections, 1998, 74(Suppl 1): S1-S11.

7. Marrazo JM et al., Performance and cost-effectiveness screening criteria for Chlamydia trachomatis infection in women: implications for a national Chlamydia control strategy, Sexually Transmitted Diseases, 1997, 24(3):131-141; Weinstock HS et al., Chlamydia trachomatis infection in women: need for universal screening in high prevalence populations, American Journal of Epidemiology, 1992, 135(1):41-47; and Welsh M, Feldblum P and Chen S, Sexually transmitted disease risk assessment used among low-risk populations in East/Central Africa: a review, East African Medical Journal, 1997, 74(12):764-771.

8. Fox LJ et al., 1995, op. cit. (see reference 5).

9. Dallabetta G, personal communication, Aug. 28, 1998.

10. Holmes KK et al., 1990, op. cit. (see reference 2); Dallabetta GA, Gerbase AC and Holmes KK, 1998, op. cit. (see reference 6); and Eng TR and Butler WT, eds., The Hidden Epidemic: Confronting Sexually Transmitted Diseases, Washington, DC: National Academy Press, 1997.

11. Miller WC, 1998, op. cit. (see reference 5); Vuylsteke B et al., 1993, op. cit. (see reference 6); Daly CC et al., Risk factors for gonorrhea, syphilis, and trichomonas infections among women attending family planning clinics in Nairobi, Kenya, Genitourinary Medicine, 1994 70(3):155-61; Mayaud P et al., Risk assessment and other screening options for gonorrhea and chlamydial infections in women attending rural Tanzanian antenatal clinics, Bulletin of the World Health Organization, 1995, 73(5):621-630; Braddick MR et al., Towards developing a diagnostic algorithm for Chlamydia trachomatis and Neisseria gonorrhoeae cervicitis in pregnancy, Genitourinary Medicine, 1990, 66(2):62-65; Thomas T et al., Identifying cervical infection among pregnant women in Nairobi, Kenya: limitations of risk assessment and symptom-based approaches, Genitourinary Medicine, 1996, 72(5):334-338; and Gertig DM et al., Risk factors for sexually transmitted diseases among women attending family planning clinics in Dar-es-Salaam, Tanzania, Genitourinary Medicine, 1997, 73(1):39-43.

12. Behets FM et al., Sexually transmitted diseases are common in women attending Jamaican family planning clinics and appropriate detection tools are lacking, Sexually Transmitted Infections, 1998, 74(Suppl 1): S147-S152.

13. Ibid.; and Behets FM et al., Management of vaginal discharge in women treated at a Jamaican sexually transmitted disease clinic: use of diagnostic algorithm versus laboratory testing, Clinical Infectious Diseases, 1995, 21(6):1450-1455.

14. Van Dyck E et al., The STD laboratory, in: Dallabetta G, Laga M and Lamptey P, eds., Control of Sexually Transmitted Diseases: A Handbook for the Design and Management of Programs, Arlington, VA, USA: Family Health International/AIDSCAP, 1996.

15. Vuylsteke B et al., 1993, op. cit. (see reference 6).

16. Marrazo JM et al., 1997, op. cit. (see reference 7); Mayaud P et al., 1995, op. cit. (see reference 11); Mosure DJ et al., Genital chlamydia infections in sexually active female adolescents: do we really need to screen everyone? Journal of Adolescent Health, 1997, 20(1):6-13; Ronsmans $C$ et al., Clinical algorithms for the screening of Chlamydia trachomatis in Turkish women, Genitourinary Medicine, 1996, 72(3):182-186; and Mayaud P et al., Risk scores to detect cervical infections in urban antenatal clinic attenders in Mwanza, Tanzania, Sexually Transmitted Infections, 1998, 74(Suppl 1):S139-S146.

17. Behets FM et al., 1998, op. cit. (see reference 12).

18. Thomas T et al., 1996, op. cit. (see reference 11); and O'Farrell N et al., Genital ulcer disease: accuracy of clinical diagnosis and strategies to improve control in Durban, South Africa, Genitourinary Medicine, 1994, 70(1):7-11.

19 Knud-Hansen CR et al., Surrogate methods to diagnose gonococcal and chlamydial cervicitis: comparison of leukocyte esterase dipstick, endocervical Gram stain, and culture, Sexually Transmitted Diseases, 1991, 18(4): 211-216.

20. Vuylsteke B et al., 1993, op. cit. (see reference 6).

21. Thomas T et al., 1996, op. cit. (see reference 11).

22. Vuystelke B et al., 1993, op. cit. (see reference 6); Daly CC et al., 1994, op. cit. (see reference 11); Mayaud P et al., 1995, op. cit. (see reference 11); Braddick MR et al., 1990, op. cit. (see reference 11); and Thomas T et al., 1996, op. cit. (see reference 11).

23. Cates W, Jr., A risk assessment tool for integrated reproductive health services, Family Planning Perspectives, 1997, 29(1):41-43; Morrison CS et al., Use of sexually transmitted disease risk assessment algorithms for selection of intrauterine device candidates, Contraception, 1999, 59(2):97-106; Vuylsteke B et al., 1993, op. cit. (see reference 6); and Mayaud P et al., 1995, op. cit. (see reference 11).

24. Thomas T et al., 1996, op. cit. (see reference 11).

25. Vuylsteke B et al., 1993, op. cit. (see reference 6); Daly
CC et al., 1994, op. cit. (see reference 11); Mayaud P et al, 1995, op. cit. (see reference 11); Braddick MR et al., 1990, op. cit. (see reference 11); and Gertig DM et al., 1997, op. cit. (see reference 11).

26. Daly CC et al., 1994, op. cit. (see reference 11); and Gertig DM et al., 1997, op. cit. (see reference 11).

27. Daly CC et al., 1994, op. cit. (see reference 11); and Vuylsteke B et al., 1993, op. cit. (see reference 6).

28. Vuylsteke B et al., 1993, op. cit. (see reference 6).

29. Ibid.

30. Mayaud P et al., 1998, op. cit. (see reference 16).

31. Kapiga SH et al., Evaluation of sexually transmitted diseases diagnostic algorithms among family planning clients in Dar es Salaam, Tanzania, Sexually Transmitted Infections, 1998, 74(Suppl 1):S132-S138.

32. Centers for Disease Control and Prevention, 1998 guidelines for treatment of sexually transmitted diseases, Morbidity and Mortality Weekly Report, 1998, 47(RR-1): 1-111.

33. Dallabetta GA, Gerbase AC and Holmes KK, 1998, op. cit. (see reference 6).

34. Meda $\mathrm{N}$ et al., Pattern of sexually transmitted diseases among pregnant women in Burkina Faso, West Africa: potential for a clinical management based on simple approaches, Genitourinary Medicine, 1997, 73(3): 188-193; Alary M et al., Evaluation of clinical algorithms for the diagnosis of gonococcal and chlamydial infections among men with urethral discharge or dysuria and women with vaginal discharge in Benin, Sexually Transmitted Infections, 1998, 74(Suppl.1):S44-S49; and Bogaerts J et al., Sexually transmitted infections in a basic healthcare clinic in Dhaka, Bangladesh: syndromic management for cervicitis is not justified, Sexually Transmitted Infections, 1999, 75(6):437-438

35. Dallabetta G, personal communication, Aug. 28, 1998.

36. Rao P et al., Systematic analysis of STD control: an operational model, Sexually Transmitted Infections, 1998, 74(Suppl 1):S17-S22.

\section{Resumen}

Contexto: Las clínicas de planificación familiar que planean agregar los servicios de atención a las infecciones de transmisión sexual (ITS), deberían considerar alternativas a los logaritmos de riesgo adaptados de la Organización Mundial de la Salud (OMS) para identificar las mujeres que están infectadas.

Métodos: Se entrevistó y examinó a una muestra de 767 clientes de planificación familiar de la ciudad de Kingston, Jamaica, de las cuales se obtuvieron muestras para detectar casos de gonorrea, clamidia y tricomonas. Se analizó el suero para detectar casos de sífilis. Los modelos de decisión para clasificar a las mujeres que tenían ITS se compararon mediante el uso de criterios clínicos y estadísticos. Los modelos incluyeron las clasificaciones de ITS con base en la suma ponderada de los factores de riesgo de las ITS; con base en la presencia de dos o más factores identificados a través de una entrevista; o con base en una entrevista aumentada con la prueba de orina (por medio del método de evaluación rápida). Estos modelos fueron comparados con el logaritmo de riesgo adaptado de la OMS, desarrollado original- 
mente para las pacientes con ITS en Jamaica. Resultados: Los factores relacionados con la infección fueron el resultado de un examen de orina leukocyte esterase dipstick (LED) superior a 1+ (lo cual indica una probabilidad de infección con base en la concentración de enzimas de glóbulos blancos, usando una escala de negativo, traza, 1+, 2+ y 3+); haber tenido varias parejas sexuales durante el último año; presencia de un cuello friable; y tener menos de 25 años de edad. Otro factor de riesgo adicional unicamente para la infección cervical (gonorrea o clamidia) era el manchado luego de relaciones sexuales. La descarga vaginal no estuvo significativamente relacionada con la infección. Para la infección cervical, el logaritmo de riesgo inclusive adaptado de la OMS fue el menos exacto (un valor positivo de predicción del 14\%), los logaritmos de riesgo ponderados resultaron ser los mejores (un valor positivo de predicción del $23 \%$ ), en tanto que la entrevista sola y la evaluación rápida de riesgo fueron un poco menos exactos (un valor positivo de predicción del 20\%).

Conclusiones: El logaritmo de riesgo inclusive adaptado de la OMS no pareció apropiado para las mujeres que no presentaban sintomas. La evaluación rápida de riesgo fue de más fácil administración y de mejor nivel de predicción. Las pruebas de orina LED pueden resultar útiles cuando no se pueden realizar los exámenes de pelvis. Para identificar mejor las mujeres que necesitan de consejería y de mayor atención médica o tratamiento, otros modelos de evaluación de las ITS — que no sean el logaritmo de la OMS-deben ser analizados en otros ambientes de alta prevalencia de ITS o donde las pacientes son poco probables de procurar mayor atención médica.

\section{Résumé}

Contexte: Les cliniques de planning familial qui prévoient l'ajout de prestations MST (maladies sexuellement transmissibles) à leurs services devraient envisager des approches autres que les algorithmes "tous risques» adaptés de l'Organisation Mondiale de la Santé(OMS) pour l'identification des femmes contaminées. Méthodes: Un échantillon de 767 clientes du planning familial de Kingston, en Jamaïque, a été soumis à des entrevues et examens, avec collecte de spécimens en vue de la détection des gonorrhées, chlamydia et trichomonas, et analyse sérique de détection de la syphilis. Les modèles décisionnels de classification des femmes atteintes de MST ont été comparés en fonction de critères cliniques et statistiques. Ces modèles incluaient la classification des MST en fonction de la somme pondérée des facteurs de risque MST, de la présence d'au moins deux facteurs identifiés dans le cadre d'une entrevue, ou d'une entrevue avec analyse d'urine (pour évaluation rapide du risque). Ces modèles ont été comparés à un algorithme adapté de l'OMS (originalement destiné aux clientes MST), précédemment validé dans cette population du planning familial.

Résultats: Les facteurs associés à l'infection se sont avérés les résultats d'analyse d'urine supérieurs à 1+ (indicateur de probabilité d'in- fection basée sur la concentration d'enzymes leucocytaires, selon l'échelle "négatif, trace, $1+, 2+$ et $3+»)$, la multiplicité des partenaires sexuels durant les 12 derniers mois, le col utérin friable et l'âge inférieur à 25 ans. Les saignotements faisant suite aux rapports sexuels représentaient également une facteur de risque d'infection cervicale seulement (gonorrhée ou chlamydia). La déclaration de leucorrhée ne s'est pas révélée significativement associée à l'infection. Pour l'infection cervicale, l'algorithme inclusif de l'OMS s'est avéré moins précis (valeur prédictive positive de 14\%); les algorithmes pondérés se sont révélés les meilleurs (valeur prédictive positive de 23\%), tandis que l'entrevue seule et l'entrevue avec évaluation rapide du risque étaient légèrement moins précises (valeur prédictive positive de $20 \%$ ).

Conclusions: L'algorithme inclusif adapté de l'OMS semble inapproprié pour les femmes asymptomatiques. L'évaluation rapide $d u$ risque est plus simple et plus prédictive. Les analyses d'urine peuvent être utiles lorsqu'un examen du bassin n'est pas possible. Les modèles d'évaluation des MST, autres que l'algorithme de l'OMS, devraient être évalués en milieux semi-urbains et ruraux, en Jamaïque comme dans d'autres milieux à prévalence MST élevée, ou où les patientes sont peu susceptibles de chercher à obtenir une évaluation approfondie, afin de mieux identifier les femmes présentant un besoin d'assistance consultative, d'évaluation approfondie ou de traitement. 